\title{
The Analysis of the Translation on Chinese Characteristic Words- Taking the Wellbeing Section in the 2017 Government Work Report as an Example
}

\author{
Xia Zhou ${ }^{*}$, Xueting Cong ${ }^{2}$
}

${ }^{1}$ Associate Professor in School of Foreign Language, North China Electric Power University, NO. 689 Road. North District, Baoding, Hebei, China

${ }^{2}$ Graduate Student in School of Foreign Language, North China Electric Power University, NO.689 Road. North District, Baoding, Hebei, China

DOI: $10.36348 /$ sijll.2021.v04i04.001

| Received: 09.03.2021 | Accepted: 07.04.2021 | Published: 11.04.2021

*Corresponding author: Xia Zhou

\section{Abstract}

As a communication activity and featuring both cross-language and cross-cultural characteristic, translation transforms the meaning of one language into another. When it comes to translating, it is inevitable to compare features in two different languages. And the research purpose is to find the proper means to translate the culture-loaded words.

Keyword: Cross-language; translation features.

Copyright ( $) 2021$ The Author(s): This is an open-access article distributed under the terms of the Creative Commons Attribution 4.0 International License (CC BY-NC 4.0) which permits unrestricted use, distribution, and reproduction in any medium for non-commercial use provided the original author and source are credited.

\section{INTRODUCTION}

Many people believe that translation means shuttling between two or more different languages and ultures.Language and culture are tied together by an indivisible bond. Altakhaineh [1]. In 2003, Sun Zhili proposed an idea which is called "culture-loaded words". He believed that many Chinese words are with rich connotations. But these words have no corresponding words with the exactly same meaning in the target language, which could be called "cultural load words." "Culture-loaded words and expressions are loaded with specific national cultural information and indicate particular national culture. They are the direct or indirect reflection of a national culture through the structure of words and expressions [2]." In Hu's opinion, he distinguishes culturally loaded words and expressions from non-culturally-loaded ones. He supposes that in the process of communication, the connotation of culture-loaded words may be extended or diminished, because a person learns a foreign language usually for the purpose of acquiring the communicative ability across cultures [2]. Lado illustrates the definition in his work [3]: "Cultureloaded words refer to the lexical items that are similar in primary meaning in both source language and target language but with different meaning in connotation." However, this definition doesn't include some cultural specific words, which specifically is a part of cultureloaded words. Mona Baker [1], Director of the Center for Translation and International Studies at the University of Manchester in England, also gives her opinion about culture-loaded words. "The words from the source text may convey a concept totally new to the target culture. Be it abstract or concrete, the concepts are culture-sensitive" In Baker's definition, the concepts mentioned can be anything related to a culture. According to Professor Wang Dechun [4], cultureloaded words are words which reflect the history, culture and customs of a country in which a certain language is used, and they bear the obvious characteristics of the national culture. According to Newmark [5], culture-loaded words, whether singleunit lexemes, phrases or collocations, are those which are particularly tied to the way of life and its manifestations. And they are peculiar to a community that uses a particular language as its means of expression. In conclusion, culture-loaded words are exclusive words that carry with culture characteristics and only the source language speakers could understand.

As society evolves, it is the same with words. Annual Government Report adds new words every year. These culturally loaded words, which are extremely crucial for China to create the image of a great and responsible country, are the most challenging task in our Chinese-English translation practice. Being a government official document, the government report represents the common characteristics of all official 
Xia Zhou \& Xueting Cong., Sch Int J Linguist Lit, Apr, 2021; 4(4): 88-92

documents and is closely related to China's socialism system and ideology. This paper will focus on three kinds of typical culture-loaded words from 2017 report on the work of the Government, namely, non-meaning but indispensable words, idioms and proverbs and words with Chinese socialist characteristic.

\section{1. non-meaning but indispensable words}

原：在当前国内外形势严峻复杂的情况下

译: Against the backdrop of challenging and complex .......

In this sentence, the translator doesn't literally translate Chinese phrase “在 ......... 情况下” into “in........situation of". Actually, they perfectly match with each other, but it may be a little bit difficult for English speakers to understand, because "in.........situation of" are not so commonly used.

\section{原: 该办能办的实事要竭力办好}

译 : Spare no effort to deliver benefit to .......Wherever possible

In Chinese, “实事”has two meanings. The first is "the items or conditions that really exist", the second comes as "the things that are really beneficial". Here " 该办能办的实事" is the second meaning, so the translator chose"deliver benefit to".

原：切实做好退役军人.........

译: We will work to see that....

Here Chinese phrases “切实做好”doesn’t have real meaning in the English version, the phrase "work to see" contains the internal meaning of “切实”. And it is more concise and explicit for English-speaking people to comprehend.

\section{原：扶持城镇困难人员}

译: help vulnerable urban residents

Here “困难” means vulnerable but not difficulty. One of the specific features in Chinese is that Chinese states ideas in a more spiral way. Therefore, the word"困难" does not really mean the difficulty rather than the statement of the conditions of urban residents.

原: 提高博士研究生国家助学金补助标准

译: we will increase government grants for.....

Here “标准” is an abstract and a category word, so the translator doesn't translate it literally. Because the literal translation bears no much meaning. But the adopted version states the core meaning of the source text. So the translation is more sensible.
原：加强教师队伍建设

译: we will work to improve teacher performance.

原：全面落实残疾人“两项补贴”制度

译: We will achieve full coverage in providing living allowances .........

原: 加强安全基础设施建设

译: We will strengthen the development of safety infrastructure

原：加大就业援助力度

译: step up employment assistance

There is no practical meaning in the category words “制度”“建设”“力度”and they are not translated. Sometimes, the typical statement or traditional expression of Chinese does not make sense when translated directly into English.

Compared with Chinese, the English words have specific meanings. This phenomenon happens because of language disparity between Chinese and English. In contrast, Chinese focuses on the completeness and accuracy of a sentence and emphasis on semantic expression, while English pays more attention to syntactic function, which means English sentences employs the word forms to express different meaning. And Chinese grammar does not involve phonetics. The word-based theory has already shown the characteristics of the basic structure unit of Chinese. The Chinese language-based rule emphasizes the meaning rather than the morphologcal changes of grammar. On the contrary, the English grammar system is strict with the grammatical rules, which is characterized by the morphological changes of words in the expression of sentences.

Taking all these factors into consideration when translating Chinese into English, one should understand the internal meaning, context, pragmatic habits of the original text, the different language characteristics, expression habits and ways of thinking between Chinese and English. It also should be noticed that Chinese is a paratactic language compared to English. In the process of translating English into Chinese, we must pay attention to the expression of meaning. And it is the same when comes to EnglishChinese. When translating a Chinese character into English, it is cannot be an easy task to translate into a completely corresponding phrase because of the hidden characteristics of Chinese grammar. When they are translated into English, the number of words will be increased to achieve the integrity of the original meaning. At the same time, this paper also found that translator use "we" more frequently when summarizing the government report, which is also related to the special style of this report. The government work report is a very formal report made by the Chinese premier in an oral form. The content of the report is mostly related to the annual work of the government. It can shorten the distance between the government and the audience, so 
that the audience becomes much closer to the government work.

For the government work report, there is a large number of non-subject sentences in the source Chinese text. And when they are translated into English, the corresponding subjects need to be added. For example, “加强安全基础设施建设”, its English translation is "We will strengthen the development of safety infrastructure".

\section{Idioms and proverbs}

In each year's report, there will also be a large number of Chinese-specific idioms and proverbs. As the basic elements of language and the carrier of culture, vocabulary reflects the culture of a specific region. And the differences between different languages also make source language difficult to find equivalent vocabularies of meaning, form or structure in the target language, resulting in vocabulary vacancy. Roughly, two reasons attribute to this phenomenon, physically and culturally, namely, geographical environment, lifestyle, religious beliefs, customs and values. How to break the language barrier caused by these differences and convey the meaning and connotation of the source language accurately and smoothly to the target language readers is worthy of continuous exploration and discovery by translators. In essence, vocabulary vacancies and culturally loaded words have the same meaning, reflecting the role of the language behind the culture. Here is some examples in the report.

\section{原：放在心头, 扛在肩上}

译 : always on our minds and the responsibility for it must never leave our shoulders.

It can be seen that verbs are frequently shown in Chinese sentences while preposition are commonly used in English.“放”is translated into “on”. Also, English uses far more conjunctions and similar connectives than Chinese. There is no conjunctions in Chinese, but "and "in English, which is because that Chinese stresses perceptional comprehension [6].

原：严而又严

译：The utmost rigor

English uses“" utmost ”to express 严而又严

原：重典治乱

译：serious violations are severely penalized

Necessary explanations and descriptive phrases are added in translation 典 refers to law

\section{原：人命关天, 安全至上}

译 : we must work with tireless dedication to ensure workplace safety

原：铸而不舍

译 : we will take continued steps to resolve .......
There is less or few exact equivalent words between Chinese and English. A word can be used in different phrases in English, all of which have similar but different meanings. Chinese stresses more on meaning while English is a grammatical structure language. In Chinese, characters can both express the meaning of a vocabulary and the meaning of a morpheme; on the contrary, the "word" in English is the independent use of language units. It can be seen that the Chinese language belongs to the "meaning-based" language, while English belongs to the "structurebased" language. For example, the sentence in the Chinese textbook "给你一盒巧克力", the explanation of the "盒"is "box", although the basic meaning of "盒 子" in the English language can be defined as "box", which belongs to a noun. However, in the Chinese language, if the "盒" does not have a suffix, it cannot be used as a "盒子", but just belongs to the measure words. Thus, only the "盒子" should be translated into "box".

\section{Words with Chinese socialist characteristics}

The culture of each country is unique, so it is the same with language. As China has developed quickly; many new words come into being in China, which have greatly increased the number of Chinese words. Those new words can result in cultural vacancy. There are currently three definitions of vocabulary vacancies: (1) vocabulary specific to their respective cultures; (2) some kind of recipient of alien culture in the original language. What is not understood, inexplicable, and misunderstood, creates a blank of alien culture [4]; (3) Words and expressions with special cultural meanings [5]. In addition, Guo Aixian sums that because of the cultural differences among different ethnic groups, the language that expresses unique things or concepts, words or semantics cannot find the equivalent elements in another language, forming a gap in the alien culture. Regarding the classification of vocabulary vacancies, the overall classification is divided into two categories: material vocabulary vacancy and cultural vocabulary vacancy. Among them, the cultural vocabulary vacancy discussed by the author is that the words with national cultural meaning and have no corresponding components in the language of another nationality. These words mainly focus on values, policies social systems, philosophical thoughts, traditional culture, historical background, etc. In addition, some people believe that there are also vacancies that divide vocabulary vacancies into form and content, that is, referential vacancy vocabulary and pragmatic meaning vacancy vocabulary. The meaning of reference is the mutual vacancy of linguistic vocabulary formed by the difference of material existence. The pragmatic meaning is the mutual vacancy of culture and emotion. The nationality of culture and the unique ways of thinking lead to the existence of vocabulary vacancy phenomenon and the difficulty of translation, but the 
Xia Zhou \& Xueting Cong., Sch Int J Linguist Lit, Apr, 2021; 4(4): 88-92

commonality of culture and thinking also provides the possibility of intercultural communication. Human interactions are accompanied by the deepening of cultural globalization. Some words that were previously impossible to communicate with has now unearthed translatability and proposed translation methods. To certain extent, these ways can at least to interpret or even extend the meaning of the source language. With the help of correct translation strategy, the translation work can be done with less effort. All these good translation can help English readers better understand Chinese culture and is also conducive to shape the image of one country.

\section{原：基本民生的底线要淣牢}

译 : ensure their basic living needs are met

原：切实做好托底工作

译 : make sure there is a social cushion in place

“䛜牢底线”“拖底”have no equivalent words in English, but the exact meaning of this phrase is people's basic living standard, and there can be found equivalent phrases in English government report.

\section{原：统一城乡义务教育学生“两免一补”政策}

译 : We will combine the separate policies for rural and urban students receiving compulsory education that waive tuition and miscellaneous fees, supply free textbooks, and grant living allowances for boarders from financially disadvantaged families.

\section{原：适应实施全面二孩政策}

译 : As the policy of allowing couples to have two children has been adopted,.......

\section{原：提高优抚、社会救助标准}

译 : we will continue raising basic pension payments and ......

\section{原：落实残疾人“两项补贴”制度}

译 : we will achieve full coverage in providing living allowances for people with disabilities in financial difficulty and nursing care subsidies for people with severe disabilities

\section{原：提高基本公共卫生服务分级诊疗试点}

译：we will extend trials to use a tiered diagnosis and treatment model and .......

\section{原：全民健身}

译：fitness - for - all initiatives

原：落实信访工作责任制

译：we will enforce the responsibility system for handling public complaints

“两免一补” “全面二孩”“优抚政策”“两项补贴”“全民 健身”“落实信访

工作制度”These are all words with Chinese characteristics. They indicate China's policies, so the internal policy implications must be translated so that foreigners can better understand our policies, bringing Chinese image to a new level."

\section{原：持续改善薄弱学校办学条件}

译 : we will continue to improve conditions in badly built and poorly operated schools

Here“薄弱学校”,is a very abstract word, in which aspect can a school be called "weak school"? What does weakness mean? There is no clear explanation in Chinese here, because the reporter assumes that all listeners know the meaning of the term, but for foreigners, it cannot be understood.

\section{原：农民工工资拖欠问题}

译 : resolve the problem of wage arrears for migrant workers

\section{CONCLUSION}

By studying all these cases, the study believes that when translating culturally loaded words, some ideas should be kept in mind: 1 . Whether the translation is appropriate from the perspective of foreigners ( whose native language is the target language); 2.The meaning of a foreign language vocabulary cannot depend only on dictionary, but also its meaning in practical use. 3. Take the economic law in translation activities into consideration, foreigners tend to use a relatively simple Chinese transliteration, and abandon the cumbersome foreign language translation; 4. When transliterating Chinese cultural load words, it can be based on Chinese Pinyin, and it should also be finetuned according to the actual situation.

\section{REFERENCES}

1. Baker, M. (2000). In Other Words: A Course book on Translation. Oxford: Oxford University Press.

2. Hu, W. (1999). Aspects of Intercultural Communication. Beijing: Foreign Language Teaching and Research Press

3. Lado, R. (1972). Teaching English as a Second Language: Patterns of Difficulty in Vocabulary. New York: McGraw-hill Companies Inc.

4. Wang, D. (1998). On Bilingual Culture-loaded Words Discrepancy. Shanghai: Shanghai Foreign Language Education Press.

5. Newmark, P. (1998). More Paragraphs on Translation. Clevedon etc.: Multilingual Matters.

6. Perception of Culturally Loaded Words by Arab EFL LearnersBy Altakhaineh, Abdel Rahman Mitib; Zibin, Aseel Simak | International Journal of Linguistics, May 1, 2014

7. 冯艳艳,李瑶. (2017). 年中国《政府工作报告》 英译本地道性探究 [J].海外英语,2018(07):129$130+135$.

8. 胡开宝,田绪军. 《政府工作报告》英译文本的语 言特征与文本效果研究一一项基于语料库的 研究[J].外国语文,2018,34(05):1-11. 
